\title{
Ovarian Leydig Cell Tumor
}

National Cancer Institute

\section{Source}

National Cancer Institute. Ovarian Leydig Cell Tumor. NCI Thesaurus. Code C5231.

A rare, benign steroid tumor that arises from the ovary and is composed of Leydig cells that contain Reinke crystals. It usually affects postmenopausal women and in most cases, is associated with androgenic manifestations. 